\title{
Antibacterial Activity of Benzyl Benzoate and Crotepoxide from Kaempferia rotunda L. Rhizome
}

\author{
Hartiwi Diastuti*, Mochammad Chasani, and Suwandri \\ Department of Chemistry, Universitas Jenderal Soedirman, \\ Jl. dr. Soeparno 61, Karangwangkal, Purwokerto 53123, Indonesia
}

* Corresponding author:

tel: $+62-8170611988$

email: hartiwidiastuti@yahoo.com

Received: July 26, 2018

Accepted: September 26, 2018

DOI: $10.22146 / \mathrm{ijc} .37526$

\begin{abstract}
Benzyl benzoate and crotepoxide are the major components of Kaempferia rotunda L. rhizome. However, the bioactivity study of benzyl benzoate and crotepoxide as the antibacterial activity were still limited. Therefore, the antibacterial activity of benzyl benzoate and crotepoxide against four pathogenic bacteria, i.e., Escherichia coli ATCC 25922, Enterococcus aerogenes ATCC 13048, Bacillus cereus ATCC 6538 and Staphylococcus aureus ATCC 11778 were investigated. The isolation steps included the extraction by maceration with acetone, and then the acetone extract was partitioned with $\mathrm{n}$-hexane:methanol (1:1) and ethyl acetate:water (1:1) respectively. The isolation by liquid vacuum chromatography followed by column chromatography was yielded benzyl benzoate from the n-hexane fraction and crotepoxide from ethyl acetate fraction. The molecular structure of isolated compounds was identified based on NMR (1D and 2D) spectroscopic data. The antibacterial activity assay of isolated compounds was carried out using the disc diffusion method. The antibacterial evaluation confirms that the benzyl benzoate and crotepoxide exhibits a medium level activity. Benzyl benzoate showed highest antibacterial activity against B. cereus with MIC of $50 \mu \mathrm{g} / \mathrm{mL}$ and inhibitory zone of $5.9 \mathrm{~mm}$, while the crotepoxide showed highest antibacterial activity against E. aerogenes with MIC of $100 \mu \mathrm{g} / \mathrm{mL}$ with inhibitory zone $6.1 \mathrm{~mm}$.
\end{abstract}

Keywords: antibacterial; benzyl benzoate; crotepoxide; K. rotunda $L$.

\section{- INTRODUCTION}

Infectious disease is one of the health problems, especially in developing countries including in Indonesia. Treatment of infectious diseases by bacteria with antibiotics has been carried out, but the ability of antibiotics gradually decreased due to the resistance of microorganism. In addition, the use of synthetic antibiotics often causes adverse effects. It encourages the researchers to get the new safe antibiotics, one of them from medicinal plants.

Kaempferia rotunda (Zingiberaceae) is a medicinal plant in Indonesia; It was known locally name as " $k u n c i$ pepet" or "kunir putih". The rhizome of $K$. rotunda was used for traditional medicine such as treating stomach pain, fever, indigestion, inflammation due to bruises or sprains, carminative and accelerate wound healing [1]. The crude extracts, volatile oils and isolated compounds from $K$. rotunda rhizome exhibited the essential biological activities. According to the previous report, extract of $K$. rotunda rhizome showed antioxidant activity [2-3], insecticides [4], anti-inflammatory [5], anthelmintic [6], antihyperglycemic and antinociceptive [7], antimicrobial [8-10] and anti-androgenic [11]. Some compounds of the $K$. rotunda rhizome also revealed some biological activities. A 2-hydroxy-4,4',6trimethoxy chalcone showed antioxidant activity with $\mathrm{IC}_{50}$ of $142 \mu \mathrm{g} / \mathrm{mL}$ [3]. Crotepoxide was the main constituent of $K$. rotunda rhizome useful for antitumor agent [5]. In the ethyl acetate and ethanol extract of K. rotunda were contain 33.11 and $42.92 \%$ crotepoxide, respectively [11]. Pinostrobin, 5,7-dihydroflavanone, and crotepoxide were exhibited anticancer activity against T470 breast cancer cell with $\mathrm{IC}_{50}$ of 59.8, 122.71 and $>1000 \mu \mathrm{g} / \mathrm{mL}$, respectively [12]. Meanwhile, benzyl 
benzoate showed insecticidal activity on Spodoptera littoralis with $\mathrm{LC}_{50}$ of $5.6 \mu \mathrm{g} / \mathrm{mL}$ [4].

The essential oil has an important role in the biological activity of $K$. rotunda, The essential oil of $K$. rotunda rhizome was contained about 75 compounds with two main compounds namely benzyl benzoate (69.7\%) and $n$-pentadecane (22.9\%) [13]. In different locations, it was also mentioned that of 20 compounds in the volatile oil of $K$. rotunda was contain benzyl benzoate $36.60 \%$ and bornyl acetate $30.15 \%$ [14]. Furthermore, it was reported that essential oils in $n$-hexane extract of K. rotunda rhizome could inhibit the growth of some bacteria [9]. The other plant study reported that Salvia urmiensis essential oil contained $60.3 \%$ benzyl benzoate showed high activity against Staphylococcus epidermis and Staphylococcus cerevisiae with minimum inhibitory of $9.3 \mu \mathrm{g} / \mathrm{mL}$ [15]. It showed that benzyl benzoate has potential as an antibacterial agent because it is the main component of $K$. rotunda essential oil.

The previous study of some extracts of $K$. rotunda rhizome suggests that the ethyl acetate and water extracts showed significant antibacterial activity against some pathogenic bacteria, whereas the antibacterial activity of benzyl benzoate and crotepoxide were still limited reported. In this article, we wish to report the isolation of the major component of $K$. rotunda rhizome as well as antibacterial properties.

\section{- EXPERIMENTAL SECTION}

\section{Materials}

Rhizome of K. rotunda (collected from Purwokerto Indonesia), silica gel plate $60 \mathrm{~F}_{254}$ aluminium sheets (Merck), silica gel 60 G (7731, 7734 and 7733, Merck), bacterial strains: E. coli ATCC 25922, E. aerogenes ATCC 13048, B. cereus ATCC 6538 and S. aureus ATCC 11778 (supplied by Microbiology Laboratory, Faculty of Medicine Unsoed Purwokerto), Muller Hinton Agar (Oxoid), chloramphenicol (Merck) and dimethyl sulfoxide (Merck).

\section{Instrumentation}

${ }^{1} \mathrm{H}$ and ${ }^{13} \mathrm{C}$-NMR (Nuclear Magnetic Resonance) spectra used Agilent DD2 spectrometer operating at 500 $\left({ }^{1} \mathrm{H}\right)$ and $125\left({ }^{13} \mathrm{C}\right)$ Mhz. Optical rotation was measured by Rudolf Research Analytical Autopol IV Auto Polarimeter.

\section{Procedure}

\section{Isolation of benzyl benzoate and crotepoxide from $\mathrm{K}$. rotunda}

Dried powder of $K$. rotunda rhizome ( $1 \mathrm{~kg})$ was extracted with acetone at room temperature. The acetone extract of $K$. rotunda rhizome filtered and concentrated using a rotary evaporator. Then the concentrated acetone extract was partitioned with $n$ hexane:methanol (1:1) and the soluble $n$-hexane extract was concentrated with a rotary evaporator. On the other hand, the soluble methanol extract was partitioned with ethyl acetate:water (1:1). Next, the ethyl acetate fraction was concentrated with a rotary evaporator.

The $n$-hexane fraction of $K$. rotunda rhizome $(20 \mathrm{~g})$ was fractionated by vacuum column chromatography on silica gel and eluted gradually with $n$-hexane, the mixture of $n$-hexane:chloroform $(7: 3,6: 4$, 5:5, 2:8 and 1:9), chloroform, and ethyl acetate. TLC analysis was carried out to all fractions with eluent $n$ hexane:chloroform (1:1). The fractions having similar spot were collected into 7 sub-fractions: F1 (9.5 g), F2 (1.3 g), F3 (0.6 g), F4 (0.2 g), F5 (0.3 g), F6 (0.3 g) and F7 $(0.5 \mathrm{~g})$. Furthermore, F1 which contains the main components of benzyl benzoate was purified by column chromatography using eluent $n$-hexane:chloroform (9:1) to yield a pure benzyl benzoate in the form of colorless oil $(543 \mathrm{mg})$. The ethyl acetate fraction of K. rotunda rhizome (6 g) was fractionated by vacuum column chromatography then eluted gradually with $n$-hexane: ethyl acetate $(8: 2,7.5: 2.5,7: 3$ and $0: 10)$ to give 5 subfraction: F1' (0.05 g), F2' (0.1 g), F3' (0.3 g), F4' (0.9 g), and F5' (1.3 g). Crotepoxide (colorless needles) was isolated from fraction $\mathrm{F} 5$ ' by column chromatography using eluent $n$-hexane:chloroform:ethyl acetate (5:5:1).

\section{Antibacterial activity assays [16]}

Selected bacteria were cultured for $24 \mathrm{~h}$ at $37{ }^{\circ} \mathrm{C}$ under aerobic conditions on agar media (Mueller Hinton Agar). Afterward, the bacteria were suspended in a $0.9 \% \mathrm{NaCl}$ solution $(\mathrm{w} / \mathrm{v})$. The turbidity of 
suspension of bacteria was corrected to the $0.5 \mathrm{Mc}$ Farland standard $\left(1-2 \times 10^{8}\right.$ bacterial cells $\left./ \mathrm{mL}\right)$.

Agar plate was inoculated with $200 \mu \mathrm{L}$ bacterial suspension. $50 \mu \mathrm{L}$ of the samples with concentrations of $10,50,100$ and $500 \mu \mathrm{g} / \mathrm{mL}$ were dripped on paper disc on agar media and incubated for $24 \mathrm{~h}$ at $37^{\circ} \mathrm{C}$. The presence of clear zones around the paper disc was indicated that the sample has antibacterial activity. The inhibitory zone of the sample was determined by measuring the diameter of the clear zone around the paper disc. The assays were also carried out to the negative control (DMSO 10\%) and standard antibiotic chloramphenicol (positive control). The assays were conducted in three repetitions.

\section{- RESULTS AND DISCUSSION}

\section{Identification of Benzyl Benzoate and Crotepoxide from $K$. rotunda Rhizome}

Benzyl benzoate (Fig. 1) was obtained as colorless oil. The ${ }^{1} \mathrm{H}-\mathrm{NMR}$ spectrum $\left(500 \mathrm{MHz}, \mathrm{CDCl}_{3}\right.$ ) of benzyl benzoate was indicated seven proton signals. They revealed an oxygenated methylene signal at $\delta 5.39,(2 \mathrm{H}, s)$, and six signals of two aromatic proton that represented $10 \mathrm{H}$ which are at $\delta 7.36(2 \mathrm{H}, t, \mathrm{~J}=7.2 \mathrm{~Hz}, \mathrm{H}-3, \mathrm{H}-5), \delta 7.41(2 \mathrm{H}, t$, $\mathrm{J}=7.2 \mathrm{~Hz}, \mathrm{H}-3^{\prime}$ and $\left.\mathrm{H}-5^{\prime}\right), \delta 7.44\left(1 \mathrm{H}, t, \mathrm{~J}=7.5 \mathrm{~Hz}, \mathrm{H}-4^{\prime}\right)$, $\delta 7.47\left(2 \mathrm{H}, d, \mathrm{~J}=7.2 \mathrm{~Hz}, \mathrm{H}-2^{\prime}, \mathrm{H}-6^{\prime}\right), \delta 7.58(1 \mathrm{H}, t, \mathrm{~J}=7.2$ $\mathrm{Hz}, \mathrm{H}-4)$, and $\delta 8.11(2 \mathrm{H}, d, \mathrm{~J}=7.5 \mathrm{~Hz}, \mathrm{H}-2, \mathrm{H}-6) \mathrm{ppm}$. Three proton triplet (H-3, H-5, and $\mathrm{H}-4$ or $\mathrm{H}-3^{\prime}, \mathrm{H}-5^{\prime}$ and $\left.\mathrm{H}-4^{\prime}\right)$ and two proton doublet (H-2, H-6 or H-2, H-6') could be assigned to phenyl groups which indicates a substituent on an aromatic ring. The ${ }^{13} \mathrm{C}$-NMR spectrum $\left(125 \mathrm{MHz}, \mathrm{CDCl}_{3}\right)$ confirmed that there are 14 carbon signals, which indicated the presence of two $\mathrm{sp}^{3}$-carbon of oxygenated methylene $\left(\mathrm{CH}_{2}-\mathrm{O}-\right)$ at $\delta 66.69(\mathrm{C}-8) \mathrm{ppm}$, a $\mathrm{sp}^{2}$-carbon of carbonyl ester group at $\delta 166.43(\mathrm{C}-7)$ ppm, two quaternary sp ${ }^{2}$-carbons at $\delta 130.15$ (C-1) and 136.07 (C-1') ppm, and ten sp ${ }^{2}$-methines at $\delta 129.70$ (C-2, C-6), $\delta 128.16$ (C-3, C-5), $\delta 133.02$ (C-4), $\delta 128.37$ (C-2', C-6'), $\delta 128.60\left(\mathrm{C}-3^{\prime}, \mathrm{C}-5^{\prime}\right)$ and $\delta 128.24\left(\mathrm{C}-4^{\prime}\right) \mathrm{ppm}$. The ${ }^{1} \mathrm{H}$ and ${ }^{13} \mathrm{C}$-NMR spectra data of benzyl benzoate (Table 1) was the newest data from published data [17], where previous data was operating at $300\left({ }^{1} \mathrm{H}\right)$ and $75\left({ }^{13} \mathrm{C}\right) \mathrm{Mhz}$.

Crotepoxide (Fig. 1) was obtained as colorless needles (mp 152-154 $\left.{ }^{\circ} \mathrm{C},[\alpha]_{D}^{22}+66^{\circ}\right)$. The ${ }^{1} \mathrm{H}$ NMR (500 $\mathrm{MHz}, \mathrm{CDCl}_{3}$ ) spectrum showed two signal for two methyl of acetyl groups at $\delta 1.96(3 \mathrm{H}, s, \mathrm{H}-11)$ and $\delta 2.05(3 \mathrm{H}, s$, $\mathrm{H}-12) \mathrm{ppm}$, five signal of the aromatic ring at $\delta 7.96(2 \mathrm{H}$,

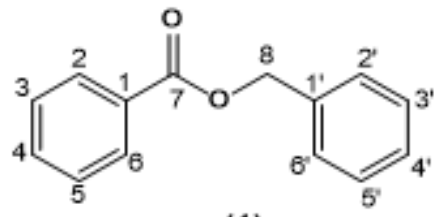

(1)

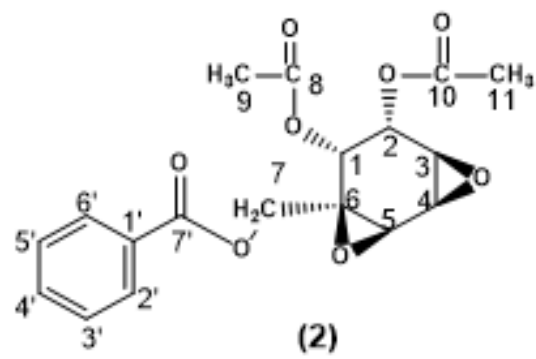

Fig 1. Benzyl benzoate (1) and Crotepoxide (2)

Table 1. HSQC and HMBC spectra of benzyl benzoate

\begin{tabular}{|c|c|c|c|}
\hline \multirow{2}{*}{$\mathrm{C}$ atom } & \multicolumn{2}{|c|}{ HSQC } & \multirow{2}{*}{$\operatorname{HMBC}\left({ }^{1} \mathrm{H} \rightarrow{ }^{13} \mathrm{C}\right)$} \\
\hline & $\delta_{\mathrm{C}} \mathrm{ppm}$ & $\delta_{\mathrm{H}}(m u l t, J \mathrm{~Hz}) \mathrm{ppm}$ & \\
\hline 1 & 130.15 & - & - \\
\hline 2,6 & 129.70 & $8.11(2 \mathrm{H}, d, 7,2)$ & $\mathrm{C}-1, \mathrm{C}-3, \mathrm{C}-4, \mathrm{C}-5, \mathrm{C}-7$ \\
\hline 3,5 & 128.16 & $7.36(2 \mathrm{H}, t, 7,2)$ & C-2, C-4, C-7 \\
\hline 4 & 133.02 & $7.58(1 \mathrm{H}, t, 7,5)$ & C-2, C-3, C-5, C-6 \\
\hline 7 & 166.43 & - & - \\
\hline 8 & 66.69 & $5.39(2 \mathrm{H}, s)$ & C-7, C-1', C-2' \\
\hline $1^{\prime}$ & 136.07 & - & - \\
\hline $2^{\prime}, 6^{\prime}$ & 128.37 & $7.47(2 \mathrm{H}, d, 7,2)$ & C-8, C-1', C-3', C-4' \\
\hline $3^{\prime}, 5^{\prime}$ & 128.60 & $7.41(2 \mathrm{H}, t, 7,2)$ & $\mathrm{C}-1^{\prime}, \mathrm{C}-2^{\prime}, \mathrm{C}-4^{\prime}$ \\
\hline $4^{\prime}$ & 128.24 & $7.44(1 \mathrm{H}, t, 7,5)$ & C-2', C-3', C-5', C-6' \\
\hline
\end{tabular}


Table 2. HSQC and HMBC spectra of crotepoxide

\begin{tabular}{|c|c|c|c|}
\hline \multirow{2}{*}{ C atom } & \multicolumn{2}{|c|}{ HSQC } & \multirow{2}{*}{$\operatorname{HMBC}\left({ }^{1} \mathrm{H} \rightarrow{ }^{13} \mathrm{C}\right)$} \\
\hline & $\delta_{\mathrm{C}} \mathrm{ppm}$ & $\delta_{\mathrm{H}}(m u l t, J \mathrm{~Hz}) \mathrm{ppm}$ & \\
\hline 1 & 59.39 & - & - \\
\hline 2 & 69.40 & $5.64(1 \mathrm{H}, d, 9.0)$ & $\mathrm{C}-1, \mathrm{C}-3$ \\
\hline 3 & 70.36 & $4.91(1 \mathrm{H}, d, 9,2)$ & $\mathrm{C}-2$ \\
\hline 4 & 52.61 & $3.03(1 \mathrm{H}, d, 5.0)$ & C-3, C-6 \\
\hline 5 & 48.07 & $3.39(1 \mathrm{H}, d d, 5.0$ and 2.7$)$ & C-6 \\
\hline 6 & 53.82 & $3.60(1 \mathrm{H}, d, 2.7)$ & C-5 \\
\hline \multirow[t]{2}{*}{7} & 62.40 & $4.50(1 \mathrm{H}, d, 12)$ & C-7’ \\
\hline & & $4.17(1 \mathrm{H}, d, 12)$ & \\
\hline 8 & 169.76 & - & - \\
\hline 9 & 20.65 & $1.96(3 \mathrm{H}, \mathrm{s})$ & - \\
\hline 10 & 170.06 & - & - \\
\hline 11 & 20.68 & $2.05(3 \mathrm{H}, \mathrm{s})$ & C- 10 \\
\hline $1^{\prime}$ & 129.08 & - & - \\
\hline $2^{\prime}, 6^{\prime}$ & 129.79 & $7.96(2 \mathrm{H}, d d)$ & C-1', C-3', C-5', C-7' \\
\hline $3^{\prime}, 5^{\prime}$ & 128.56 & $7.39(2 \mathrm{H}, t)$ & C-4', C-2', C-6' \\
\hline $4^{\prime}$ & 133.56 & $7.53(1 \mathrm{H}, t)$ & C-2', C-3', C-5', C-6' \\
\hline $7^{\prime}$ & 165.78 & - & - \\
\hline
\end{tabular}

m, H-2', H-6'), $\delta 7.39$ (2H, $\left.m, \mathrm{H}-3^{\prime}, \mathrm{H}-5^{\prime}\right)$ and $\delta 7.53(1 \mathrm{H}$, $\left.m, \mathrm{H}-4^{\prime}\right) \mathrm{ppm}$, three signal for oxygenated protons $\delta 3.39$ $(1 \mathrm{H}, d d, \mathrm{~J}=2.5$ and $3.9 \mathrm{~Hz}, \mathrm{H} 4), \delta 3.08(1 \mathrm{H}, d d, \mathrm{~J}=0.8$ and $3.5 \mathrm{~Hz}, \mathrm{H} 5)$ and $\delta 3.60(1 \mathrm{H}, \mathrm{d}, \mathrm{J}=2.7 \mathrm{~Hz}, \mathrm{H} 6) \mathrm{ppm}$, two signal for oxygenated protons at $\delta 5.64(1 \mathrm{H}, \mathrm{d}, 9.0 \mathrm{~Hz})$ and $\delta 4.91(1 \mathrm{H}, \mathrm{d}, 9.0 \mathrm{~Hz}) \mathrm{ppm}$, and two signal for $\mathrm{AB}$ system at $\delta 4.50(1 \mathrm{H}, \mathrm{J}=12.0 \mathrm{~Hz}, \mathrm{H}-7)$ and $4.17(1 \mathrm{H}, \mathrm{J}=$ $12.0 \mathrm{~Hz}, \mathrm{H}-7) \mathrm{ppm}$. The ${ }^{13} \mathrm{C}-\mathrm{NMR}$ spectra $(125 \mathrm{MHz}$, $\mathrm{CDCl}_{3}$ ) of crotepoxide revealed the presence two of methyl of acetyl carbons at $\delta 20.65$ (C-9) and 20.68 (C-11) ppm, six aromatic carbon at $\delta 129.08$ (C-1'), 129.79 (C-2' and C-6'), 128.56 (C-3' and C-5'), and 133.56 (C-4') ppm, a methylene carbon at $62.40(\mathrm{C}-7) \mathrm{ppm}$, three carbonyl esters at $\delta 169.76(\mathrm{C}-8), 170.06(\mathrm{C}-10)$ and 165.78 (C-7') ppm, five methine carbons at $\delta 60.40(\mathrm{C}-2), 70.36(\mathrm{C}-3)$, 52.51 (C-4), 43.07 (C-5) and 53.82 (C-6) ppm, and two quaternary carbons at $\delta 59.39$ (C-1) and 129.08 (C-1') ppm. The ${ }^{1} \mathrm{H}$ and ${ }^{13} \mathrm{C}$-NMR spectra data of crotepoxide was in agreement with the published data [18].

The one bond correlation between carbon and proton is determined by the $2 \mathrm{D}$ (two-dimensional) NMR spectrum of HSQC (Heteronuclear Single Quantum Coherence), whereas the correlation of two or three bonds between carbon and proton is determined by the HMBC
(Heteronuclear Multiple Bond Coherence) spectra. Table 1 and 2 represents the $1 \mathrm{D}\left({ }^{1} \mathrm{H}\right.$ and ${ }^{13} \mathrm{C}$ ) and $2 \mathrm{D}$ (HSQC and $\mathrm{HMBC}$ ) of benzyl benzoate and cretopoxide spectra data. Meanwhile, Fig. 2 describes the correlation of two or three bonds between proton and carbon (HMBC) on the benzyl benzoate and crotepoxide structures.

\section{Antibacterial Activity}

Antibacterial activity assays of extract and isolated compounds were conducted on four pathogenic bacteria including two Gram-negative bacteria E. coli ATCC 25922
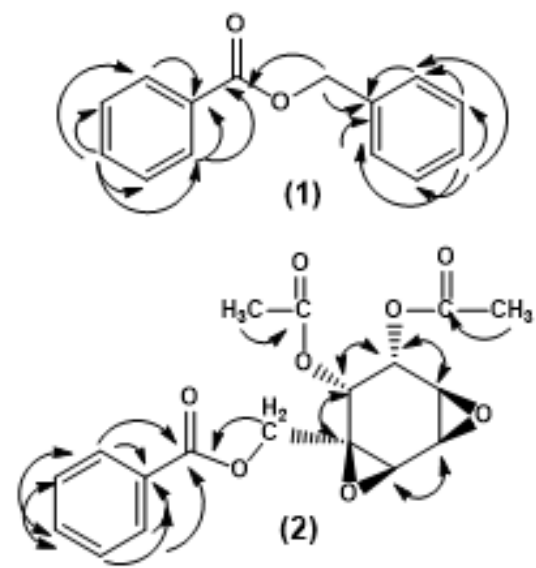

Fig 2. HMBC of benzyl benzoate (1) and crotepoxide (2) 
Table 3. Antibacterial activity of extract, fraction and isolated compounds of $K$. rotunda rhizome

\begin{tabular}{|c|c|c|c|c|c|}
\hline \multirow{3}{*}{ Sample } & \multirow{3}{*}{$\begin{array}{c}\text { Concentration } \\
(\mu \mathrm{g} / \mathrm{mL})\end{array}$} & \multicolumn{4}{|c|}{ Zone inhibitory $(\mathrm{mm}) \pm \mathrm{SD}$} \\
\hline & & E. coli & E. aerogenes & B. cereus & S. aureus \\
\hline & & ATCC 25922 & ATCC 13048 & ATCC 6538 & ATCC 11778 \\
\hline \multirow[t]{4}{*}{ Acetone extract } & 10 & - & - & - & $3.1 \pm 0.06$ \\
\hline & 50 & $3.4 \pm 0.03$ & - & - & $5.4 \pm 0.26$ \\
\hline & 100 & $8.0 \pm 0.03$ & $4.3 \pm 0.17$ & $3.6 \pm 0.06$ & $8.1 \pm 0.17$ \\
\hline & 500 & $11.7 \pm 0.17$ & $7.9 \pm 0.02$ & $10.1 \pm 0.36$ & $12.1 \pm 0.36$ \\
\hline \multirow[t]{4}{*}{$n$-Hexane fraction } & 10 & $4.2 \pm 0.11$ & $3.0 \pm 0.06$ & $4.1 \pm 0.03$ & $4.0 \pm 0.06$ \\
\hline & 50 & $8.2 \pm 0.06$ & $8.1 \pm 0.11$ & $7.9 \pm 0.17$ & $10.0 \pm 0.03$ \\
\hline & 100 & $11.1 \pm 0.36$ & $12.2 \pm 0.86$ & $15.9 \pm 0.01$ & $15.2 \pm 0.26$ \\
\hline & 500 & $20.2 \pm 0.06$ & $18.9 \pm 0.03$ & $19.8 \pm 0.66$ & $19.5 \pm 0.50$ \\
\hline \multirow[t]{4}{*}{ Ethyl acetate fraction } & 10 & - & - & - & - \\
\hline & 50 & - & $6.9 \pm 0.11$ & - & - \\
\hline & 100 & - & $9.5 \pm 0.01$ & - & $2.4 \pm 0.26$ \\
\hline & 500 & $5.0 \pm 0.03$ & $11.8 \pm 0.36$ & $3.6 \pm 0.36$ & $4.1 \pm 0.17$ \\
\hline \multirow[t]{4}{*}{ Benzyl benzoate } & 10 & - & - & - & - \\
\hline & 50 & - & - & $5.9 \pm 0.06$ & $3.6 \pm 0.06$ \\
\hline & 100 & $5.2 \pm 0.17$ & $4.0 \pm 0.06$ & $8.1 \pm 0.06$ & $6.1 \pm 0.06$ \\
\hline & 500 & $7.0 \pm 0.03$ & $8.9 \pm 0.17$ & $9.9 \pm 0.11$ & $9.1 \pm 0.06$ \\
\hline \multirow[t]{4}{*}{ Crotepoxide } & 10 & - & - & - & - \\
\hline & 50 & - & - & - & - \\
\hline & 100 & - & $6.1 \pm 0.03$ & $4.2 \pm 0.03$ & - \\
\hline & 500 & - & $8.6 \pm 0.36$ & $7.0 \pm 0.11$ & $3.8 \pm 0.06$ \\
\hline \multirow[t]{4}{*}{ Chloramphenicol } & 10 & $14.2 \pm 0.36$ & $10.9 \pm 0.06$ & $15.0 \pm 0.03$ & $15.0 \pm 0.50$ \\
\hline & 50 & $27.0 \pm 0.17$ & $15.2 \pm 0.25$ & $20.0 \pm 0.03$ & $25.7 \pm 0.11$ \\
\hline & 100 & $31.9 \pm 0.01$ & $24.0 \pm 0.03$ & $27.0 \pm 0.01$ & $28.2 \pm 0.06$ \\
\hline & 500 & $34.7 \pm 0.36$ & $27.3 \pm 0.17$ & $30.7 \pm 0.17$ & $31.9 \pm 0.06$ \\
\hline
\end{tabular}

$\mathrm{SD}=$ Standard Deviation

and E. aerogenes ATCC 13048, and two Gram-positive bacteria B. cereus ATCC 6538 and S. aureus ATCC. Antibacterial assays were also performed on acetone extract, $n$-hexane and ethyl acetate fractions of $K$. rotunda rhizome.

The results of antibacterial activity assay to acetone extract, $n$-hexane and ethyl acetate fraction, and isolated compounds of $K$. rotunda rhizome was indicated different inhibitory zone to all test bacteria (Table 3). All sample tests showed the lower antibacterial activity than positive control (chloramphenicol). The inhibitory zone level of bacterial growth is classified as follows: weak $(<5 \mathrm{~mm})$, moderate (5-10 mm), strong (11-20 mm) and very strong (> $21 \mathrm{~mm})$ [19].

Acetone extract of $K$. rotunda rhizome showed moderate activity against $E$. coli and $S$. aureus with an inhibitory zone of 8.0 and $8.1 \mathrm{~mm}$ at $100 \mu \mathrm{g} / \mathrm{mL}$ concentrations, and it exhibits high antibacterial activity (11.7 and $12.1 \mathrm{~mm}$ ) at $500 \mu \mathrm{g} / \mathrm{mL}$. While on E. aerogenes and B. cereus at $500 \mu \mathrm{g} / \mathrm{mL}$ showed inhibitory zone 7.9 and $10.1 \mathrm{~mm}$, respectively. The $n$-hexane fraction of the $K$. rotunda rhizome showed antibacterial activity against all test bacteria. The $n$-hexane fraction of $K$. rotunda rhizome showed moderate activity at $50 \mu \mathrm{g} / \mathrm{mL}$ with the inhibitory zone 7.9 to $10.0 \mathrm{~mm}$. The intense activity (11.1-20.2 mm) of the $n$-hexane fraction was shown at $100 \mu \mathrm{g} / \mathrm{mL}$ and $500 \mu \mathrm{g} / \mathrm{mL}$. Both acetone extract and $n$ hexane fraction $K$. rotunda rhizome are potential as an antibacterial. The ethyl acetate fraction showed 
antibacterial activity against $E$. aerogenes at a minimum concentration of $50 \mu \mathrm{g} / \mathrm{mL}$ with an inhibitory zone of $6.9 \mathrm{~mm}$, however to the other bacteria showed weak activity.

The benzyl benzoate have lower activity than acetone extract and $n$-hexane fraction; it is suggested that the other compounds both in acetone extract and $n$ hexane fraction of $K$. rotunda rhizome have higher antibacterial activity than benzyl benzoate. Synergism is observed when the effect of combined substances is greater. Benzyl benzoate showed moderate antibacterial activity against $B$. cereus at $50-500 \mu \mathrm{g} / \mathrm{mL}$ with an inhibitory zone of $5.9-9.9 \mathrm{~mm}$, against $E$. coli and $S$. aureus at $100-500 \mu \mathrm{g} / \mathrm{mL}$ with an inhibitory zone of 5.27.0 and $6.1-9.1 \mathrm{~mm}$ respectively, and to E. aerogenes at $500 \mu \mathrm{g} / \mathrm{mL}$ with an inhibitory zone of $8.9 \mathrm{~mm}$.

Meanwhile, crotepoxide exhibited moderate antibacterial activity against $E$. aerogenes at $100-500 \mu \mathrm{g} / \mathrm{mL}$ with an inhibitory zone $6.1-8.6 \mathrm{~mm}$ and against $B$. cereus at $500 \mu \mathrm{g} / \mathrm{mL}$ with inhibitory zone $7.0 \mathrm{~mm}$, while to other bacteria do not have activity. Its suggested that crotepoxide have lower activity than ethyl acetate fraction, except against $B$. cereus.

Generally, crotepoxide showed lower antibacterial activity than benzyl benzoate. This is possible because both compounds have a different structure, functional groups, and lipophilicity. The lipophilicity of compounds was affected by their ability to penetrate the cell wall of bacteria. The cell wall of bacteria has the lipid layers (lipophiles) that make these bacteria more resistant against some compounds and impermeable with limited diffusion [20]. Crotepoxide has lower lipophilicity than benzyl benzoate; therefore its ability to penetrate the bacteria cell wall was less than benzyl benzoate.

The antibacterial activities of essential oil and their components or some cyclic hydrocarbon compounds have been previously reviewed and the mechanism of action has not been studied in great detail, because most of the cyclic hydrocarbon compounds showed to have no specific cellular targets. Such as typical lipophiles, they pass through the cell wall and cytoplasmic membrane, disrupt the structure of their different layers of polysaccharides, fatty acid, and phospholipids. They can coagulate the cytoplasm and damage lipids and protein [21].

\section{- CONCLUSION}

The benzyl benzoate and crotepoxide from $K$. rotunda rhizome were successfully isolated. The evaluation of antibacterial activity of benzyl benzoate and crotepoxide against four pathogenic bacteria confirmed that benzyl benzoate and crotepoxide have lower antibacterial activity than acetone extract and $n$ hexane fraction of $K$. rotunda rhizome. The benzyl benzoate was exhibited the highest antibacterial activity with moderate classification against $B$. cereus at a minimum concentration of $50 \mu \mathrm{g} / \mathrm{mL}$ and inhibitory zone $5.9 \mathrm{~mm}$ whereas crotepoxide showed the highest activity against $E$. aerogenes at a minimum concentration of $100 \mu \mathrm{g} / \mathrm{mL}$ with inhibitory zone $6.1 \mathrm{~mm}$.

\section{- REFERENCES}

[1] Kim, T.K., 2016, Edible Medicinal and NonMedicinal Plants, Springer-Cham, Switzerland.

[2] Desmiaty, Y., Winarti, W., Nursih, A.M., Nisrina, H., and Finotory G., 2018, Antioxidant and antielastase activity of Kaempferia rotunda and Curcuma zedoaria, Res. J. Chem. Environ., 22 (1), 95-98.

[3] Lotulung, P.D.N., Minarti, Kardono, L.B.S., and Kawarrishi, K., 2008, Antioxidant compound from the rhizomes of Kaempferia rotunda, Pak. J. Biol. Sci., 11 (20), 2447-2450.

[4] Nugroho, B.W., Schwarz, B., Wray, V., and Proksch, P., 1996, Insecticidal constituents from rhizomes of Zingiber cassumunar and Kaempferia rotunda, Phytochemistry, 41 (1), 129-132.

[5] Imam, S.A., Rout, S.K., Sutar, N., Sharma U.S., and Sutar, R., 2013, Wound healing activity of Kaempferia rotunda Linn leaf extract, Int. J. Curr. Microbiol. Appl. Sci., 2 (12), 74-78.

[6] Agrawal, S., Bhawsar, A., Choudhary, P., Sing, S., Keskar, N., and Chaturvedi, M., 2011, In-vitro anthelmintic activity of Kaempferia rotunda, Int. J. Pharm. Life Sci., 2 (9), 1062-1064. 
[7] Sultana, Z., Imam, K.M.S.U., Azam, F.M.S., Rahman, S., Rahman, S., Islam, F., and Rahmatullah, M., 2012, Evaluation of antihyperglycemic and antinociceptive activities of methanolic extract of Kaempferia Rotunda L. (Zingiberaceae) rhizomes, Adv. Nat. Appl. Sci., 6 (8), 1302-1306.

[8] Kabir, S.R., and Reza, M.A., 2014, Antibacterial activity of Kaempferia rotunda rhizome lectin and its induction of apoptosis in Ehrlich ascites carcinoma cells, Appl. Biochem. Biotechnol., 172 (6), 2866-2876.

[9] Kumar, A., Kumar, S., and Navneet, 2015, Antimicrobial activity and phytochemical analysis of Kaempferia rotunda L. rhizomes, Pharm. Lett., 7 (9), 389-395.

[10] Astutiningsih, C., Octaviani, R., and Suratiningsih, S., 2014, Daya hambat minyak atsiri dan ekstrak limbah sisa destilasi rimpang kunir putih (Kaempferia rotunda L.) terhadap pertumbuhan Candida albicans ATCC 10231, J. Pharm. Sci. Community, 11 (1), 18-22.

[11] Suphrom. N., Sonyot, W., Insumrong, K., Sawangsup, P., Sutamuang, P., and Ingkaninan, K., 2017, GC-MS analysis and in vitro anti-androgenic activity of Kaempferia rotunda Linn extract, Naresuan Univ. J. Sci. Technol., 25 (4), 34-43.

[12] Atun, S., and Arianingrum, R., 2015, Anticancer activity of bioactive compounds from Kaempferia rotunda rhizome against human breast cancer, Int. J. Pharmacogn. Phytochem. Res., 7 (2), 262-269.

[13] Woerdenbag, H.J., Windono, T., Bos, R., Riswan, S., and Quax, W.J., 2004, Composition of the essential oil of Kaempferia rotunda L. and Kaempferia angustifolia Roscoe rhizomes from Indonesia, Flavour Fragr. J., 19 (2), 145-149.
[14] Sereena, K., Kumar, U.P., and Shree, A.B.R., 2011, Histochemical and phytochemical markers for the authentication of ayurvedic raw drug hallakam (Kaempferia rotunda) and its marketed adulterant, Int. J. Pharm. Sci. Res., 2 (11), 2952-2958.

[15] Farjam, M.H., 2012, Comparative study of the antimicrobial activity of essential oil and two different extracts from Salvia urmiensis Bunge, Asian Pac. J. Trop. Biomed., 2 (3), 2-4.

[16] Balouiri, M., Sadiki, M., and Ibnsouda, S.K., 2016, Methods for in vitro evaluating antimicrobial activity: A review, J. Pharm. Anal., 6 (2), 71-79.

[17] Sindra, H.C., and de Mattos, M.C.S., 2016, Appel reactions of carboxylic acid with tribromoisocyanuric acid/triphenylphosphine: A mild and acid-free preparation of esters and amides, J. Braz. Chem. Soc., 27 (6), 1129-1136.

[18] Desta, Z.Y., and Sewald, N,. 2018, Isolation of noncytotoxic crotepoxide from the root bark of Croton macrostachyus and the reassignment of its structure, Bull. Chem. Soc. Ethiop., 31 (3), 465-469.

[19] Rumengan, I.F.M., Rumampuk, N.D., Rimper, J., and Losung, F., 2014, Produksi dan uji aktivitas antimikroba senyawa bioaktif yang diekstrak dari rotifer (Brachionus rotundiformis) strain lokal, Jurnal LPPM Bidang Sains dan Teknologi, 1 (1), 56-70.

[20] Mangunwardoyo, W., and Deasywaty, U.T., 2012, Antimicrobial and identification of active compound Curcuma xanthorrhiza Roxb., IJBASIJENS, 12 (1), 69-78.

[21] Tripathi, M., Chawla, P., Uphadyay, R., and Trivedi, S., 2013, Essential oils from family Zingiberaceae for antimicrobial activity - A review, IJPBS, 4 (4), 149-162. 